\title{
Rekrutteringsstrategier og problemer i et grønlandiseringsperspektiv
}

I de grønlandske medier debatteres visionerne for selvstændighed. I denne debat er der to poler. Den ene hævder, at grønlandsk selvstændighed kan opnås gennem ansættelse af personer med etnisk grønlandsk oprindelse. Det hævdes, at de veluddannede grønlændere, som kan påtage sig de kompetencetunge stillinger, findes. Årsagen til, at de ikke besætter stillingerne, er, at der foregär en diskriminering mod veluddannede grønlændere på det grønlandske arbejdsmarked. Synspunktet modsiges af de, som hævder, at det grønlandske samfund er gennemsyret af nepotisme, hvilket opleves ved politiske udnævnelser til bestyrelser og politisk pres for ansættelse af bestemte personer i ansættelsessammenhænge. I artiklen analyseres argumenterne for henholdsvis det ene og det andet synspunkt. Konklusionen taler for, at det grønlandske samfund i nogen grad er præget af politisk indblanding, også i konkrete ansættelsessager.
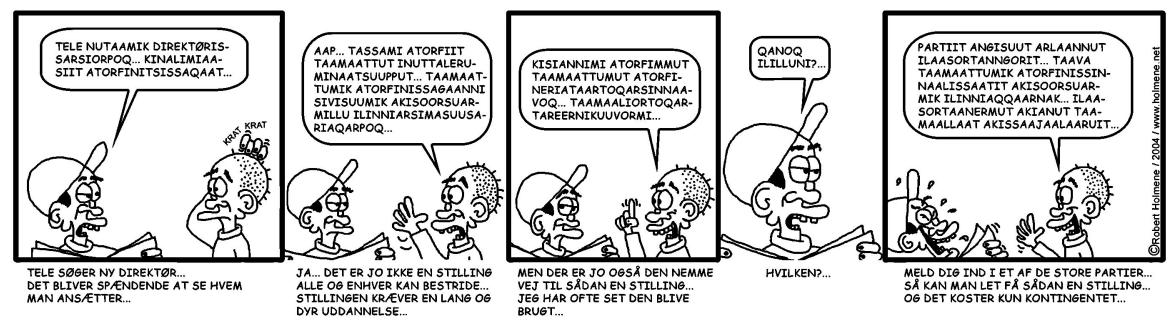

Buuarsikkut af Robert Holme

De grønlandske medier - Sermitsiaq, $A G$ og $K N R$ - er for tiden (medio maj 2008) præget af to debatter. Én debat omhandler omfanget af nepotisme i det grønlandske samfund. En anden debat vedrører Selvstyrekommissionens betænkning, der blev overdraget til Statsminister Anders Fogh Rasmussen og Landsstyreformand Hans Enoksen den 6. maj 2008 i Katuaq. ${ }^{1}$

Selvstyrekommissionens arbejde lægger op til, at der fra den 21. juni 2009 indføres selvstyre, hvis det grønlandske folk stemmer ja til selvstyre ved en folkeafstemning. Efter en periode med selvstyre kan Grønland gå over til national selvstændighed, hvilket dog forudsætter en selvbærende økonomi uden bloktilskud fra Danmark.

Debatten om nepotisme angår flere forhold. Boligskandalen, der i Danmark blev kendt i udsendelsen Flugten fra Grønland (sendt på DR1 31.10.2007), er et illustrativt eksempel på den nepotisme, som angives at præge Grønland. Skandalen består i, at 11 lukrative boliger er solgt til langt under markedspri- 
sen til de politikere og embedsmænd, der har haft ansvaret for udformningen og administrationen af den lovgivning, der muliggjorde salget af boligerne. De 11 politikere og embedsmænd har opnået en samlet rabat på 8,8 millioner, hvilket vil sige, at personerne har sikret sig selv et skattefrit løntillæg på i gennemsnit $800.000 \mathrm{kr}$. Men boligskandalen er kun én blandt mange sager, hvor spørgsmålet om nepotisme og magtmisbrug i det grønlandske samfund rejses.

Direktøren for Air Greenland, Michael Binzer, citeres i såvel danske som grønlandske medier for, at det grønlandske erhvervsliv og den offentlige administration er gennemsyret af nepotisme i form af kammerateri, hvor loyale partifæller udnævnes på baggrund af deres loyalitet og ikke deres kvalifikationer. I Berlingske Tidende (3. april 2008) sætter Binzer trumf på, idet han forbinder de to debatter - nepotisme og grønlandsk selvstændighed - ved at hævde, at nepotismen i det grønlandske samfund truer opnåelsen af grønlandsk national selvstændighed.

Denne artikel stiller spørgsmålet: Hvilke forhold såvel samfundsmæssige som virksomhedsledelsesmæssige gør sig gældende, når det offentlige og virksomheder i Grønland skal rekruttere personale? Spørgsmålet om nepotisme og magtmisbrug i det grønlandske samfund; såvel som de samfundsmæssige overvejelser, der vedrører udviklingen af et selvbærende grønlandsk samfund i såvel social, politisk som økonomisk henseende, berøres derfor. Udviklingen af et selvbærende grønlandsk samfund er forudsætningen for at Grønland kan blive en selvstændig nation (Grønlandsk-dansk selvstyrekommission, 2008a). Denne proces hen mod et selvbærende grønlandsk samfund betegnes: grønlandisering. Grønlandisering opstilles som en modstilling til den daniseringsproces, der forgik under og lige efter kolonitiden (og som nogen mener fortsat foregår). Målet er selvstændighed, men hvorledes selvstændighed indløses, hersker der stor uenighed om. Artiklen beskæftiger sig med to forskellige syn på, hvilke midler der forventes at kunne indfri visionen for fremtidens Grønland.

Indledningsvis opstilles en teoretisk ramme, der anvendes gennem artiklen. Efterfølgende redegøres der kortfattet for to poler i grønlandiseringsdebatten, der anviser to forskellige midler til, hvorledes Grønland kan blive et selvbærende samfund i såvel økonomisk, social som politisk sammenhæng. Herefter redegøres der for Grønlands udvikling fra koloni til Hjemmestyre og dér, hvor vi står i dag: over for selvstyre. Den beskrivelse fører frem til en oversigt over Grønlands situation lige nu - specielt i forhold til Grønlands økonomi, uddannelsesniveau og andre forhold med relevans for arbejdsmarkedet i Grønland. Dette afsnit efterfølges af en analyse af 23 kvalitative interviews af personer med ansættelseskompetence. Disse interviews kan anvendes til at sige noget om de udfordringer, der opleves af respondenterne, når de skal rekruttere personale. En af de oplevede udfordringer er at blive udsat for politisk pres $\mathrm{i}$ 
forhold til at ansætte bestemte personer. Spørgsmålet er dog, hvorfor dette politiske pres opstår.

\section{Samarbejdsoverskud og organiseringsformer}

Easton definerede i 1953 det politiske problem som spørgsmålet om „den autoritative fordeling af goder for et samfund“ (Easton, 1953: 129). Definitionen af politik tilsiger en todimensional beskrivelse af „politisk“. Den ene dimension angår opfattelsen af samfundet som et politisk fællesskab, mens den anden dimension angår opfattelsen af, hvorledes goder skal fordeles. Definitionen kan generaliseres til at omhandle fællesskaber generelt, hvor samfund er et specialtilfælde af et fællesskab. Definitionen kan derfor også anvendes i forhold til at analysere organisering i fællesskaber som eksempelvis virksomheder og den offentlige administration i Grønland.

Samarbejdet mellem flere individer muliggør produktionen af flere goder, end det er muligt at producere, såfremt hver enkelt producerede goder for sig selv. Et eksempel kan illustrere dette. Hvis man har fire fangere, der hver for sig tager ud på jagt, vil de alle (eller nogle af dem) kunne fange en sæl. Forestiller man sig derimod, at de samarbejder, vil muligheden opstå for at fange en hval. En sådan hval indeholder væsentligt mere kød end fire sælers kød tilsammen. Differencen mellem de fire sælers kød og hvalens kød er samarbejdsoverskuddet. Samarbejdsoverskud kan fordeles mellem de fire fangere; og samarbejde er således potentielt til fordel for de involverede parter. Dette forudsætter dog, at individernes aktiviteter koordineres, og herefter at der er enighed om, hvorledes samarbejdsoverskuddet skal fordeles. Det politiske problem er således givet ved sammenkædningen af et muligt samarbejdsoverskud med et fordelingsproblem, som ikke har nogen automatisk løsning (Poulsen, 2004).

I forhold til problemstillingen - rekruttering og organisering i den of-fentlige administration og erhvervsvirksomhederne i Grønland - kan der angives fire forskellige organiseringsformer til produktion af et samarbejdsoverskud og en følgende anvisning på fordelingen af dette.

\section{Organiseringsformernes klassifikationsprincip}

Definitionen af det politiske problem tilsiger, at ændringer i organisering af samarbejdsrelationer vil være motiveret af en forventning om, at samarbejdsoverskuddet kan forøges ved en inklusion (eller en eksklusion) af medlemmer og eller grupper i et fællesskab. Debatten i de grønlandske medier drejer sig netop om, hvem der er legitime medlemmer af det grønlandske samfund, og i forlængelse heraf hvor stor en andel af goderne, hvilke medlemmer (eller ikkemedlemmer) har ret til. I det følgende redegøres der for artiklens klassifikation af organiseringsformer. 
Organiseringsformer kan klassificeres efter to hovedsynspunkter: 1. Hvor egalitært eller hierarkisk er organiseringen af samarbejdet? 2. Hvor konkrete eller abstrakte er de forestillinger, der gør organiseringen af samarbejdet meningsfuld?

Forestillinger og ideer indeholder viden, følelser og normative standarder (Piaget, 1970). Politiske forestillinger og ideer anviser hvorledes samarbejde og fordeling af goder skal organiseres (Ankersen, 2006: 45-46). Ideer og forestillinger kan være mere eller mindre abstrakte. I forhold til ideer om organiseringen af samarbejde er det karakteristiske for konkrete ideer, at de personer (eller grupper), der indgår i samarbejdsrelationen, er angivet konkret. Klassifikation af organiseringsformer i henhold til de to hovedsynspunkter fremgår af figur 1. Klassifikationen følger i høj grad Durkheims og Webers arbejde (Durkheim, 2000; Weber, 1991), således som det fremstilles i Poulsen og Ankersen (Poulsen, 2004; Ankersen, 2006).

Figur 1. Klassifikation af organiseringsformer

\begin{tabular}{|c|c|c|}
\hline & $\begin{array}{l}\text { Konkrete } \\
\text { sociale objekter }\end{array}$ & $\begin{array}{l}\text { Abstrakte } \\
\text { sociale objekter }\end{array}$ \\
\hline $\begin{array}{l}\text { Egalitært struktureret } \\
\text { samarbejde } \\
\text { Hierarkisk struktureret } \\
\text { samarbejde }\end{array}$ & $\begin{array}{l}\text { Konformitetsbaseret } \\
\text { (mekanisk) organisering (1) } \\
\text { Hierarkisk konformitets- } \\
\text { baseret organisering (2) }\end{array}$ & $\begin{array}{l}\text { Komplementaritetsbaseret } \\
\text { egalitær organisering (4) } \\
\text { Bureaukratisk (legal } \\
\text { rationel) organisering (3) }\end{array}$ \\
\hline
\end{tabular}

Den første organiseringsform er konformitetsbaseret (mekanisk). Organiseringen er tillidens grænser, som er givet ved fælles ritualer, der understreger konformitet og derved gør andre til forudsigelige samarbejdspartnere, fordi man kan bruge sig selv som model. Forestillingerne, som gør samarbejdet meningsfuldt, er dannet i tilknytning til de konkrete sociale objekter, som indgår i de fælles ritualer. Det typiske sociale objekt i forhold til denne organiseringsform er et totem eller et flag.

Den hierarkiske konformitetsbaserede organisering er illustreret i den organiske myte, der anskuer samfundet som en organisme, hvor nogle dele naturligt er mere essentielle for funktionen af organismen end andre. Samfundet anskues i tråd med myten som et fællesskab af naturlige sociale grupper, der har forskellige roller og værdi for funktionen af fællesskabet (Poulsen, 2004).

Grønlands arbejdsmarkedspolitik afspejler den konformitetsbaserede idé. Af denne fremgår det, at grønlandsk arbejdskraft har førsteret til arbejde i Grønland. Organisering angiver således en vigtig gruppe og en mindre vigtig gruppe i samfundet - grønlændere og tilkaldte. Grønlændere har ret til positiv særbehandling, hvormed der angives, at de har fortrinsret til goder. Positiv særbehandling kan anses for en nødvendighed, såfremt grønlandiseringen skal 
medføre, at Grønland bliver selvbærende i politisk og social henseende. Bagsiden er dog, at idet det kan være svært at definere, hvad en rigtig grønlænder er, bliver det op til den enkelte eller de politiske vinde at definere dette. Hermed er der åbnet for nepotisme givet ved, at venner, familie eller bekendte favoriseres. Argumentet for dette vil være, at venner, bekendte og familie, ved vi positivt, er rigtige grønlændere. Prioriteringen af upartiskhed og af kvalifikationer er dermed blevet besværliggjort.

Det abstrakte sociale objekt, som initierer til dannelse af komplementaritetsbaserede hierarkiske forestillinger om samarbejde og fordeling af goder, er den detaljerede regelsamling, der beskriver kompetencer inden for en bureaukratisk arbejdsdeling. Weber er en fremtrædende repræsentant for beskrivelsen af denne organiseringsform, herunder også de problemer, der er forbundet med denne organiseringsform (Weber, 1991: 196-240). Weber beskriver, at den upartiskhed og individualitet, der hersker ved den legale rationalitet, gør relationer upersonlige og kolde. Dette skyldes, at konkrete forhold som køn, etnicitet og andet skal udelades i relationernes organisering og derfor også i rekrutteringen. Styrken ved denne organiseringsform er den præcise angivelse jobfunktioner og de kvalifikationskrav, der er specificeret i tilknytning hertil.

Den komplementaritetsbaserede egalitære organiseringsform er angi-vet ved forestillinger dannet i tilknytning til abstrakte sociale objekter som menneskerettighederne og individuelle rettigheder som den demokratiske stemmeret. Det grønlandske politiske demokrati bygger således på denne organiseringsform, hvor enhver dansk statsborger over 18 år, som har boet i Grønland mere end et halvt år, har stemmeret. I forhold til organiseringen på arbejdsmarkedet er denne organiseringsform af mindre betydning.

I det følgende analyseres grønlandiseringsdebattens to poler i den ovenfor skitserede organiseringsoptik.

\section{Visioner for et selvbærende grønlandsk samfund}

I det følgende fremstilles to visioner for grønlandiseringen, som findes i den nutidige debat. Den første vision er, at der skal forgå en uddannelsesmæssig opkvalificering af den grønlandske arbejdsstyrke. Tida Ravn, tidligere kontorchef for Direktoratet for Selvstyre, hævder eksempelvis i Webavisen, at såfremt „... Grønland skal bevæge sig fra at være et tilskudssamfund til et overskudssamfund, skal uddannelse prioriteres“ (Ravn, 2005). Hun udtaler endvidere: „Vi må opbygge den kompetence, landet har brug for, for at kunne klare sig selv" (Ravn, 2005). Hun argumenterer således for, at uddannelsesniveauet ikke er tilstrækkeligt højt til, at grønlandsk arbejdskraft kan overtage mange af de uddannelsesmæssigt kompetencekrævende stillinger. På lignende vis argumenterer Binzer for en øget professionalisering af det grønlandske samfund. 
Han udtaler: „Hvis vi skal sikre os, at vi får økonomisk selvstændighed, så er vi nødt til at have et professionelt erhvervsliv, der opererer på professionelle vilkår. Ikke efter de politiske vinde, der blæser" (Binzer til Berlingske Tidende, 3 . april 2008). I Binzers forståelse forårsager nepotismen i det grønlandske samfund et spild af økonomiske ressourcer. Grønland er p.t. ikke økonomisk selvbærende, og såfremt Grønland ønsker at blive et selvstændigt land, skal det, ifølge Binzer, nepotismen til livs, ligesom professionalismen nødvendigvis må øges (Binzer til Berlingske Tidende, 3. april 2008). Binzer og Ravn angiver således, at midlet til at opnå et selvstændigt grønlandsk samfund er, at uddannelsesniveauet og professionalismen styrkes. Man kan kort beskrive denne holdning som en tilgang, der prioriterer, at Grønland bliver selvbærende i økonomisk henseende; og at dette skal ske gennem en prioritering af en bureaukratisk styreform i erhvervslivet. Truslen mod grønlandsk selvstændighed er nepotisme, forstået som en tildeling af goder på baggrund af familie, bekendtskabs- og/eller venskabsrelationer.

I modsætning til prioriteringen af uddannelse og den bureaukratiske organiseringsform anser Elisabeth Ravn Johansen - formand for selvstændighedsbevægelsen Inussuk - samt Lars-Emil Johansen - medlem af Landstinget for Siumut og medlem af Folketinget for Grønland - visionen for fremtidens grønlandisering i en ændring af arbejdsmarkeds-politikken.

Elisabeth Ravn Johansen beskriver sin og Inussuks vision for grønlandiseringen som en nationalistisk vision (Johansen, 2007b). Grønlandiseringen definerer hun således: „Vores definition på grønlandisering er en suveræn magt og et suverænt ansvar for det grønlandske folk“ (Johansen, 2007a). I indlægget i Sermitsiaq udtaler hun videre:

„Ifølge vores tankegang er det det grønlandske folk, der skal styre landet, og ikke den tilkaldte arbejdskraft ... [S] elvstændighedsbevægelsen Inussuk mener ikke, at grønlandiseringen er vellykket, hvorfor vi fristes til at sige, at en regrønlandisering med en mere stram arbejdspolitik bør gennemføres ... [M] ed udgangspunkt i de faktualiteter, der er i dag, er det meget tydeligt, at den tilkaldte arbejdskraft spænder ben for den hjemmehørende arbejdskraft ... [D]et er blevet hverdagskost, at en hjemmehørende alt for tit og ofte bliver forbigået for en tilkaldt“ (Johansen, 2007a).

Ovenstående udtalelse demonstrerer, at Johansen skelner mellem to grupper i det grønlandske samfund og i forlængelse heraf, at hun tillægger dem forskellig værdi. Der er medlemmerne af det grønlandske folk og den tilkaldte arbejdskraft; og Grønland skal styres af det grønlandske folk. Det er således den hierarkiske konformitetsbaserede organisering, som hun finder meningsfuld.

Lars-Emil Johansen er ligeledes fortaler for en grønlandisering igennem en hierarkisk konformitetsbaseret organisering af arbejdsmarkedet. I nedenstå- 
ende citat fremgår det, at Lars-Emil Johansen mener, at grønlandiseringsprocessen skal føre til, at grønlændere med erfaring og uddannelsesmæssige kvalifikationer placeres på lederposter. Han skriver, at disse grønlændere findes, og at opgaven består i at få fat på dem. Han formulerer det således:

„Vi må have grønlændere på lederposter alle steder nu ... [g]rønlændere, der med erfaring og uddannelse som ballast kan løfte opgaverne på en betryggende og kompetent måde. Disse grønlændere findes. Hjemme i Grønland, men også i Danmark og det øvrige udland. Dem skal vi have fat i“ (Johansen, 2003).

Lars-Emil. Johansen er således på linje med Elisabeth Ravn Johansen i forståelsen af, at der findes veluddannet grønlandsk arbejdskraft. Problemet består hovedsageligt $\mathrm{i}$ at stoppe diskrimineringen, få grønlænderne til at påtage sig lederstillinger og få veluddannede grønlændere til at flytte til Grønland (Johansen, 2003).

Elisabeth Ravn Johansens og Lars-Emil Johansens visioner for et selvstændigt Grønland går således i mindre grad gennem en satsning på en langsigtet økonomisk strategi, men derimod på en grønlandisering gennem en kulturelt orienteret strategi. Hermed er der aftegnet to forskellige syn på, hvorledes organiseringen i det grønlandske erhvervsliv og den offentlige administration kan medvirke til, at Grønland bliver et selvbærende samfund.

De to synspunkter i grønlandiseringsdebatten kan groft sagt opdeles efter, om de forestillinger, de baserer sig på, er dannet i tilknytning til abstrakte eller konkrete sociale objekter. Organiseringsformen, som Johansen og Johansen advokerer for, baserer sig på forestillinger dannet i tilknytning til konkrete sociale objekter. Der skelnes skarpt mellem tilkaldte - danskere - og grønlændere - dem der fødes og begraves i Grønland. Tillidens grænse går for dem ved grønlændere. I deres perspektiv kan man ikke forvente, at tilkaldte vil udvise et engagement i det grønlandske sam-fund, og det vil derfor være ressourcespild at investere i dem. I deres perspektiv opnås det grønlandske samarbejdsoverskud derfor bedst gennem en satsning på grønlændere. Den form for organisering, som Johansen og Johansen advokerer for, forbinder Binzer med nepotisme, eftersom det primære kvalifikationskrav ikke er uddannelse; men derimod grønlandsk fødestedskriterium.

Binzer og Ravn taler derimod for en organiseringsform, som er baseret på forestillinger dannet i tilknytning til det abstrakte sociale objekt: den detaljerede regelsamling. Den beskriver kompetencer inden for en bureaukratisk arbejdsdeling. Tillidens grænse er således givet abstrakt (og upartisk) i form af tillid til beskrivelsen af arbejdsdelingen i form af jobspecifikationer, som matches af passende uddannelsesmæssige kvalifikationer. Besættelsen af en stilling skal derfor ikke bero på viden om en ansøgers personlige konkrete karakteristika som eksempelvis fødested og køn, men derimod på personens faglige kvalifi- 
kationer. En sådan organiseringsform anser Johansen og Johansen for en fortsat daniseringsproces, som spænder ben for, at Grønland kan regeres på grønlandske præmisser.

I det følgende redegøres der for Grønlands økonomi, uddannelsesni-veau og relevante arbejdsmarkedsforhold.

\section{Grønland - et lille stort land}

Danske medier har igennem nogen tid belyst skandalesager i Grønland. På den anden side kan en stor politisk begivenhed som et kommunalvalg, hvor kommunalbestyrelserne for fire nye storkommuner i Grønland vælges, forbigås $\mathrm{i}$ total tavshed $\mathrm{i}$ DR's nyhedsudseendelse kl. 21 den 8. april 2008, hvor valget fandt sted. Som bosiddende i Grønland oplever man, at danskeres viden om og interesse for Grønland udelukkende begrænser sig til skandalesagerne, mens et reelt engagement og den viden, der (kan) følge(r) heraf er ikke-eksisterende.

Der kan være mange grunde til den manglende viden om grønlandske forhold. I forhold til at besvare spørgsmålet om, hvilke forhold, der gør sig gældende, når det offentlige og virksomheder i Grønland skal rekruttere personale, redegøres der indledningsvis for såvel politiske, sociale som økonomiske forhold ved Grønland, der er relevante for en forståelse af, hvorfor de personer, der ansætter folk, har de overvejelser, som de nu har. Formålet med dette afsnit er derfor i meget generelle overskrifter at beskrive det grønlandske samfund i social, politisk og økonomisk henseende.

\section{Fra koloni til bjemmestyre til ambitionen om selvstendighed gennem selvstyre}

Grønland er verdens største ø med et areal på 2.166.086 km², og heraf er 81 pct. dækket af indlandsis. Grønlands nordligste punkt er Kap Morris Jesup, som ligger $740 \mathrm{~km}$ fra Nordpolen. Det sydligste punkt i Grønland er Nunap Isua, der ligger på omtrent samme breddegrad som Oslo. Afstanden mellem det nordligste og det sydligste punkt er $2.670 \mathrm{~km}$. Afstanden mellem øst og vest i Grønland er på det bredeste sted $1.050 \mathrm{~km}$ (Grønlands Statistik, 2007a: 63). Afstanden fra Thule til Nuuk er cirka den samme som afstanden fra København til Nuuk. I sammenligningen med forholdene i Danmark er Grønland således et ganske stort land, hvor Danmark stort set kan placeres i Godthåbfjordens fjordsystem!

I 1721 rejste den norske præst Hans Egede til Grønland for at finde nordboere. Han fandt ingen nordboere. I stedet grundlagde han kolonien Godthåb, som blev den første koloni under dansk styre i Grønland. Skydsbjerg skriver, at „[d]et er karakteristisk for kolonitiden, at alle overordnede beslutninger om Grønland blev taget i Danmark“ (Skydsbjerg, 1999: 10). I begyndelsen af det 20. århundrede gennemgår Grønland ændringer i erhvervs- 
strukturen, således at fiskeri frem for fangst af havpattedyr får en større betydning (Skydsbjerg, 1999: 11). Denne ændring i erhvervsstrukturen leder dog ikke til nogen umiddelbar ændring i den danske kolonipolitik over for Grønland (Skydsbjerg, 1999: 15).

2. verdenskrig og de politiske ændringer, der fulgte i kølvandet på denne, ændrede grundlæggende på Danmarks politik i forhold til Grønland. Under 2. verdenskrig havde USA overtaget forsyningen af Grønland. Finansieringen af forsyningerne forgik ved salg af mineralet kryolit, som anvendes i aluminiumfremstilling.

Efter 2. verdenskrig blev FN oprettet, og heraf fulgte et fokus på afkolonisering. Endvidere havde eksporten af kryolit vist, at Grønland var i stand til at finansiere egne forsyninger på et højere niveau end det, Danmark havde tilbudt. På baggrund af blandt andet disse forhold blev der udarbejdet en betænkning i 1950 betegnet G50. Med denne blev der lagt op til gennemgribende modernisering af det grønlandske samfund (Skydsbjerg, 1999: 16).

Tre år efter G50 i 1953 ved ændringen af den danske grundlov fik Grønland status som et dansk amt. 26 år senere i 1979 fik Grønland Hjemmestyre. Med hjemmestyreloven igangsættes en proces med det formål at overføre den politiske myndighed, og det økonomiske og forvaltningsmæssige ansvar fra Danmark til Grønland. Processen, hvormed der overføres myndighed fra Danmark til Grønland, kan betegnes som en grønlandiseringsproces (Tobiassen, 1998: 166).

I resuméet af den grønlandsk-danske selvstyrekommissions betænk-ning om selvstyre i Grønland fremgår det: „Efter 20 år med selvstyre var stort set samtlige sagsområder, som kan overtages i henhold til hjemmestyreloven, overtaget" (Grønlandsk-dansk selvstyrekommission, 2008b: 2). Områderne, som er overtaget, opregnes i selvstyrekommissionens betænkning således:

\begin{abstract}
„Over en årrække er en række væsentlige sagsområder overtaget af hjemmestyret, herunder Grønlands indre styrelsesordning, skatter og af-gifter, folkekirken, fiskeri på territoriet, jagt, landbrug og renavl, sociale forhold, arbejdsmarkedsforhold, undervisning og kultur, erhvervsuddannelser, erhvervsforhold i øvrigt, sundhedsvæsen, boligområdet og miljøbeskyttelse. I det følgende redegøres der for befolkningsudviklingen i Grønland fra hjemmestyrets indførelse" (Grønlandsk-dansk selvstyrekommission, 2008b: 2).
\end{abstract}

Yderligere overtagelse af områder skal baseres på princippet om overensstemmelse mellem rettigheder og pligter, hvilket vil sige, at Grønlands økonomi skal finansiere udgifterne til områderne, der overtages, uden at bloktilskuddet hæves (Grønlandsk-dansk selvstyrekommission, 2008b: 5).

De områder, som ikke kan overtages af et eventuelt selvstyre, er følgende: statsforfatningen, udenrigspolitik, forsvars- og sikkerhedspolitik, højesteret, 
statsborgerskab og valuta- og pengepolitik (Grønlandsk-dansk selvstyrekommission, 2008b: 4).

\section{Grønlands befolkning $i$ og uden for Grønland}

Tabel 1 er en oversigt over den etniske befolkningssammensætning i Grønland pr. 1. januar 2007. Det fremgår af tabel 1, at der i 2007 boede 56.648 mennesker i Grønland. Af de 56.648 mennesker er 50.366 født i Grønland, hvilket svarer til 88,9 pct. af befolkningen i Grønland. Det fremgår endvidere, at 6.282 er født uden for Grønland - primært i Danmark (eller på Færøerne). Sammenlagt er der 502 personer i Grønland, som ikke har dansk statsborgerskab. I alt har 11,1 pct. af befolkningen anden etnisk baggrund end grønlandsk.

Det betyder, at langt den største etniske minoritet i Grønland er personer med dansk statsborgerskab, som ikke er født i Grønland. I praksis vil det sige, at etniske grønlændere er majoriteten i Grønland, mens etniske danskere (inkl. færinger) er en relativt stor minoritetsgruppe.

Tabel 2 er en oversigt over, hvor mange etniske grønlændere, der bor henholdsvis i Danmark og i Grønland. Det fremgår af tabellen, at rundt regnet 20 pct. af den etniske grønlandske befolkning bor i Danmark, mens 80 pct. bor i Grønland. ${ }^{2}$ Til sammenligning bor under 6 pct. af den danske befolkning i udlandet (292.871).

Tabel 1. Befolkningen pr. 1. januar 2007 i Grønland fordelt efter stats-borgerskab særskilt for fødested Grønland og fødested uden for Grøn-land.

\begin{tabular}{lrrr}
\hline & $\begin{array}{r}\text { Fødested i } \\
\text { Grønland }\end{array}$ & $\begin{array}{r}\text { Fødested uden } \\
\text { for Grønland }\end{array}$ & I alt (N) \\
\hline Danmark og Færøerne & 50.357 & 5.789 & 56.146 \\
Øvrige nordiske land & 3 & 184 & 187 \\
Baltiske lande & - & 4 & 4 \\
Europa & 4 & 126 & 130 \\
Rusland/Ukraine & - & 8 & 8 \\
Mellemøsten & - & 3 & 3 \\
Amerika & - & 30 & 30 \\
Afrika & - & 1 & 1 \\
Syd- og Mellemamerika & - & 6 & 6 \\
Asien & - & 118 & 119 \\
Australien, New Zealand & - & 13 & 13 \\
samt øvrige Oceanien & 88,9 & 11,1 & 100 \\
Procent & 50.366 & 6.282 & 56.648 \\
\hline I alt (N) & &
\end{tabular}

Anmærkning: Født i Grønland er ikke et præcist mål for hjemmehørende eller „grønlænder“. Det bemærkes dog, at der ifølge Sundhedsprofilundersøgelsen fra 1994 er god overensstemmelse mellem fødested og følelsen af at være grønlænder, jf. Grønlands Statistiks udgivelse: Ledighed i Byerne 2006 p. 14.

Kilde: Grønlands Statistik (2007). - Statistisk Årbog pp. 107-108 
Tabel 2. Personer født i Grønland fordelt efter bopæl i Danmark og Grønland pr. 1 januar 2007. Procentfordelt

\begin{tabular}{lrrr}
\hline & Bopæl i Grønland & Bopæl i Danmark & I alt \\
\hline I alt pct. & 79,9 & 21,1 & 100 \\
$\mathrm{~N}$ & 50.366 & 13.482 & 63.848 \\
\hline
\end{tabular}

Anmærkning: Født i Grønland er ikke et præcist mål for hjemmehørende eller „grønlænder". Det bemærkes dog, at der ifølge Sundhedsprofilundersøgelsen fra 1994 er god overensstemmelse mellem fødested og følelsen af at være grønlænder, jf. Grønlands Statistiks udgivelse: Ledighed i byerne 2006 p. 14.

Kilde: Grønlands Statistik (2007). Grønland 2007 - Statistisk Årbog pp. 76, (samt jf. tabel 3). Endvidere Grønlands statistik (Grønlands Statistikbank): http:// bank.statgreen.gl/statgren/database/gronland/Befolkning/Befolkning.asp, Personer født i Grønland og bosat i Danmark efter alder, tid og køn.

\section{Arbejdsmarkedet}

Det følgende er en redegørelse for ledigheden og produktiviteten i Grønland. Gennemgangen baserer sig på tal fra henholdsvis Danmarks statistik (Statistik Banken) og Grønlands statistik (Statistik Banken og Årbogen 2006 og 2007).

I Grønland var der i 2006 i gennemsnit 1.543 personer ledige. Heraf var de 1.541 af grønlandsk oprindelse, mens to personer var af dansk etnisk oprindelse. Det er således grønlænderne i Grønland som er ledige, mens personer med anden etnisk oprindelse er i arbejde (Grønlands Statistik, 2007b: 1; samt supplerende oplysninger fra Grønlands statistik).

Tabel 3. Arbejdsløshedsprocent i Grønland gennemsnit for 2006 særskilt for personer med grønlandsk etnisk baggrund og personer med anden etnisk oprindelse end grønlandsk.

\begin{tabular}{lcc}
\hline & Arbejdsløshedsprocent & I alt (N) \\
\hline Grønlandsk etnisk baggrund & 5,6 & 1.541 \\
Anden etnisk baggrund end grønlandsk & 0,0 & 2 \\
I alt & 5,6 & 1.543 \\
\hline
\end{tabular}

Anmærkning: Født i Grønland er ikke et præcist mål for hjemmehørende eller „grønlænder“. Det bemærkes dog, at der ifølge Sundhedsprofilundersøgelsen fra 1994 er god overensstemmelse mellem fødested og følelsen af at være grønlænder, jf. Grønlands Statistik (2007b: 14).

Kilde: Grønlands Statistik (2007b: 1) samt supplerende oplysninger fra Grønlands statistik.

Til sammenligning var ledigheden i Danmark i fjerde kvartal 2004 på 5,8 pct. Ledigheden for personer med dansk etnisk oprindelse var på 5,3 pct., mens den for personer med anden etnisk baggrund end dansk var på 12,9 pct. (Dan- 
marks Statistik - Statistik Banken). Ledighedsprocenterne i Grønland og Danmark er således nogenlunde ens. Men ledigheden i Danmark er mindre for personer med dansk etnisk oprindelse, mens den er større for gruppen af personer med anden etnisk baggrund. Det modsatte gør sig gældende i Grønland. Forskellen i ledigheden mellem de etniske grupper (i begge lande) skyldes sandsynligvis i høj grad forskel i uddannelsesniveauet mellem de etniske grupper. I Danmark er personer med dansk etnisk oprindelse relativt veluddannede i modsætning til personer med anden etnisk oprindelse. I Grønland er den grønlandske befolkning dårligere uddannet - de har derfor en højere ledighed.

Tabel 4. Beskæftigelsen opgjort i årsværk i 2003 og 2004 særskilt for fødested i Grønland og fødested uden for Grønland. Procentfordelt

\begin{tabular}{lccc}
\hline & Født i Grønland & Født uden for Grønland & I alt \\
\hline Årsværk i procent & 75 & 25 & 100 \\
Ârsværk produceret & 21.082 & 6.928 & 28.010 \\
\hline
\end{tabular}

Anmærkning: Født i Grønland er ikke et præcist mål for hjemmehørende eller „grønlænder“. Det bemærkes dog, at der ifølge Sundhedsprofilundersøgelsen fra 1994 er god overensstemmelse mellem fødested og følelsen af at være grønlænder, jf. Grønlands Statistik (2007b: 14).

Kilde: Grønlands Statistik (2007a: 331).

Ledighed blandt personer født i Grønland afspejles i samfundsproduktiviteten. I 2004 blev der i Grønland produceret 28.010 årsværk/fuldtidsstillinger (Grønlands Statistik, 2007a: 331). 21.082 af disse årsværk blev produceret af personer født i Grønland, mens 6.928 blev produceret af personer med anden etnisk oprindelse end grønlandsk. Det betyder, at 25 pct. af de årsværk, der produceres i Grønland, produceres af personer, der ikke er født i Grønland - primært danskere. Dette skal ses i forhold til, at andelen af personer, som ikke er født i Grønland, udgør lidt mere end 10 pct. af befolkningen. I det følgende gennemgås den grønlandske elites sammensætning.

\section{Besettelsen af elitepositionerne i det gronlandske samfund}

Christiansen og Togeby undersøger med data fra år 2000 den grønland-ske elites etniske sammensætning og reflekterer deres resultater i forhold til nogle normative krav til elitens sammensætning. De to mest centrale krav er, at rekrutteringen til eliten skal være åben, og at eliten i et rimeligt omfang skal afspejle befolkningens sammensætning (2004: 81-82).

Christiansen og Togeby påpeger, at det er urealistisk at forvente, at sammensætningen af den grønlandske elite på så relativt kort tid - 21 år - kan have 
ændret sig fra næsten total dansk dominans til at modsvare befolkningssammensætningen (2004: 83).

Christiansen og Togeby angiver, at under ét er 57 pct. af Grønlands elite grønlændere, mens 40 pct. er danskere, og 4 pct. er uoplyst eller har en tredje nationalitet (2004: 84). Forskellen mellem sektorerne er dog stor. På det politiske område er alle politikere, der indgår i undersøgelsen, grønlændere med undtagelse af én dansker. På det forvaltningsmæssige område og det erhvervsmæssige område er der en overvægt af danskere, idet danskerne inden for disse områder besætter omkring to tredjedel af elitepositionerne (2004: 84).

Den politiske elite er således totalt domineret af grønlændere (Christiansen og Togeby, 2004: 86). På den anden side er den forvaltningsmæssige og erhvervsmæssige elite domineret af danskerne. Det normative krav om, at elitens sammensætning skal afspejle befolkningssammensætningen, var således i 2000 hverken opfyldt på det politiske, det administrative eller det erhvervsmæssige område. Siden år 2000 er der dog sket markante ændringer. Politikken fra landsstyrets side har været grønlandisering gennem rekruttering af grønlændere. Den administrerende direktør for Hjemmestyret Kaj Kleist har argumenteret for politikken ved udtalelsen: „Mennesker, der er født her i landet, og som påtænker at blive begravet her, har nu en gang den bedste tilgang og den bedste motivering for at servicere deres landsmænd" (Kleist til Sermitsiaq 30.11.2007). Landstyret angiver således en grønlandisering ud fra fødestedskriterier, hvilket svarer til en konformitetsbaseret mening for organiseringen af den offentlige administration.

\section{Uddannelsesniveauet i Gronland}

Uddannelsesmuligheder i Grønland er siden Hjemmestyrets indførsel blevet udbygget betydeligt (Tobiassen, 1998: 176). Spørgsmålet er dog, hvad uddannelsesniveauet i Grønland rent faktisk er. Økonomen Christen Sørensen beskriver situationen i Grønland således: „[A]rbejdsstyrkens uddannelsesniveau er klart lavere (i Grønland) end i lande med et tilsvarende omkostningsniveau, samt at der stadig er alt for mange unge, der ikke tager en kompetencegivende uddannelse“ (Sørensen, 2007: 6). Sørensen skønner, at 75 pct. af den grønlandske arbejdsstyrkes højeste gennemførte uddannelse er folkeskolen, mens kun 5 pct. skønnes at have afsluttet en højere videregående uddannelse (Sørensen, 2007: 6). Af dette følger, at cirka 20 pct. af den grønlandske arbejdsstyrke har en kompetencegivende (mellemlang) uddannelse. 25 pct. af den grønlandske arbejdsstyrke har således en kompetencegivende uddannelse. Til sammenligning er tallet i de øvrige nordiske lande mellem 60 pct. og 85 pct. (Nordic Council of Ministers, 2006: 128).

I forhold til at rekruttere uddannet arbejdskraft med grønlandsk etnisk baggrund demonstrerer tallene, at veluddannet grønlandsk arbejdskraft er en meget 
knap ressource. En prioritering af uddannelsesmæssigt kvalificeret arbejdskraft vil derfor ofte implicere, at denne arbejdskraft skal hentes i Danmark (eller fra andre lande). En organisering i erhvervslivet og den offentlige administration efter en bureaukratisk model vil derfor naturligt føre til, at mange kvalifikationstunge stillinger besættes med danskere. Det vil ligeledes naturligt medføre, at arbejdssproget bliver dansk i stedet for grønlandsk. Derudover kan det forventes, at organisationen vil være præget af manglende kontinuitet, idet danskeren kan formodes at nære et ønske om at vende tilbage til Danmark inden for en overskuelig fremtid. Skyggesiden af den bureaukratiske organisering kan således forventes at være en fortsat daniseringsproces.

\section{Grønlands økonomi}

„Den grønlandske økonomi er på nuværende tidspunkt meget afhængig af to kilder; fiskeriet af rejer, hellefisk og krabber, samt bloktilskuddet fra Danmark“" (Grønlands Statistik, 2006: 219). I Statsministerens svar af 25. februar til Finansudvalget opgøres statens tilskud i 2007 til det grønlandske Hjemmestyre til 3,289 milliarder plus 850 millioner i udgifter til de områder - politi, retsvæsen og fiskeri-inspektion - der ikke er overtaget af Hjemmestyret (Statsministeriet, 2008: 7). Det samlede tilskud til Grønland fra den danske stat svarer til, at hver skatteborger i Danmark i gennemsnit betaler $872 \mathrm{kr}$. hvert år til medborgerne i Grønland. ${ }^{3}$ Og det betyder også, at hver enkelt borger i Grønland i princippet kunne modtage $73.065 \mathrm{kr}$.

Tilskuddet, som i princippet kunne være på mere end $250.000 \mathrm{kr}$. til hver familie i Grønland, beskriver Paldam som et tilskud, som i stedet går til den offentlige sektor - herunder driften af de grønlandske statsforetagender (2000: 33). Paldam hævder, at offentlig produktion koster knap 30 pct. mere i gennemsnit, end hvis den samme ydelse blev produceret på et marked med konkurrence (2000: 37). Det leder frem til spørgsmålet om, hvorvidt bloktilskuddet bliver brugt hensigtsmæssigt i forhold til at gøre den grønlandske økonomi selvbærende.

Såfremt folk, som Binzer hævder det, ansættes i stillinger i det grønlandske erhvervsliv og den offentlige forvaltning på grund af deres (parti-)loyalitet frem for deres kvalifikationer, kan der argumenteres for, at det ikke er forventeligt, at Grønlands økonomi bliver selvbærende inden for en overskuelig fremtid. Prioriteringen af det grønlandske samfund som økonomisk selvbærende peger på, at organiseringen af den offentlige administration og erhvervslivet i Grønland i højere grad end i dag skal basere sig på en professionel bureaukratisk organisering, hvor kvalifikationer og økonomisk effektivitet prioriteres frem for hensynet til personlige relationer. Problemet med en sådan organiseringsform vil dog være, at mange stillinger skal besættes med arbejdskraft, som ikke har grønlandstilknytning fordi arbejdsstyrkens uddannelsesniveau er relativt dårligt. 


\section{Opsummering af situationen i Grønland}

I Grønland foregår der en grønlandiseringsdebat. I denne debat hævder den ene pol, at grønlændere er parate til at overtage kompetencetunge stillinger. Et selvbærende politisk og socialt Grønland er derfor inden for rækkevidde. Fra den anden side i debatten hævdes det, at det grønlandske samfund er gennemsyret af nepotisme i form af politisk indblanding i rekrutteringsprocesser. Det hævdes ligeledes, at såfremt Grønland ønsker selvstændighed på et økonomisk bæredygtigt grundlag, er det afgørende, at uddannelsesniveauet hæves, og at nepotismen i samfundet erstattes af professionalisme.

I forhold til de to positioner i debatten skal det her fremføres, at uddannelsesniveauet i Grønland er relativt lavt. Det klinger derfor hult, når politikere og embedsmænd påstår, at der findes kvalificerede grønlændere til at besætte stillingerne - det tyder tallene simpelthen ikke på. Endvidere viser tallene, at lidt mere end 10 pct. af den grønlandske befolkning er folk med primært dansk etnisk oprindelse. De 10 pct. af befolkningen tegner sig for 25 pct. af de årsværk, der produceres i Grønland. Yderligere besætter folk med dansk etnisk oprindelse en relativt stor del af den erhvervsmæssige og forvaltningsmæssige elite (om end det må formodes, at denne andel er faldende). Disse forhold må uundgåeligt føles frustrerende; og der må derfor naturligt opstå en motivation for at ansætte personer med grønlandsk etnisk oprindelse - også selvom de faglige kvalifikationer måske ikke er helt i orden. Problemhorisonten er således angivet for de personer, der skal rekruttere personale.

\section{Rekruttering til arbejdsmarkedet i Grønland}

I det ovenstående skitseredes det problemfelt, som en arbejdstager skal agere $\mathrm{i}$, når der skal rekrutteres arbejdskraft i Grønland. De vigtigste forhold i problemfeltet kan beskrives således: Elitepositionerne i det grønlandske er på det forvaltningsmæssige og det erhvervsmæssige område i relativt stor grad (formodentlig fortsat) domineret af danskere. På det politiske område er den grønlandske dominans total. Fra denne side lyder der et krav om en gennemgribende grønlandisering gennem ansættelse af grønlændere, hvilket vil bringe diskriminering af velkvalificerede grønlændere til ophør. Ud fra de normative krav, som Christiansen og Togeby opstiller, er dette uacceptabelt, såfremt det er korrekt ... Men er det korrekt?

Kahlig gennemførte i 1990'erne en kvalitativt baseret undersøgelse (Kahlig, 1999). Han konkluderer, at der foregår en diskriminering, således at tilkaldte danskere foretrækkes frem for grønlændere med det samme kvalifikationsniveau (1999: 218). Siden Kahligs undersøgelse er der gået omkring ti år, hvor grønlandiseringen har været på såvel den politiske som den mediemæssige dagsorden. Spørgsmålet er, hvorvidt der er sket ændringer. Og hvis der er sket ændringer, hvori disse ændringer består. Er det således, som Bintzer hævder, 
at stillinger besættes ud fra hensyn, der kan karakteriseres som nepotisme? Eller er det faglige kvalifikationer, der vægtes højest i en ansættelsessituation? Eller er det alternativt således, at det er beherskelsen af det grønlandske sprog, der lægges mest vægt på i en ansættelsessituation?

\section{Design og metode}

I metodeundervisningen på Institut for Administration gennemførte vi i forårssemesteret 2007 interviews med 23 personer i det grønlandske samfund, der alle har ansættelseskompetencer. Disse er ansat i forskellige grønlandske virksomheder, i Hjemmestyrets administration og i Nuuk kommune.

Interviewguiden, som interviewene laves med udgangspunkt i, er relativt åbent struktureret. Vi ønsker at få respondenten til at reflektere over de overvejelser, som han eller hun har, når vedkommende skal ansætte folk. I interviewene indgår der altid spørgsmål om, hvad fordelene og ulemperne er ved at ansætte henholdsvis en dansker og en grønlænder. Endvidere indgår spørgsmålet om, hvem personen ville foretrække, såfremt han eller hun kunne vælge mellem to lige kvalificerede ansøgere - henholdsvis en dansker og en grønlænder.

Figur 2. Kategoriseringen „kompetencer“, som efterspørges i det grønlandske erhversliv og den offentlige administration fordelt på, om ansøgeren har grønlandstilknytning og/eller fagspecifikke kompetencer

\begin{tabular}{|c|c|c|}
\hline & Grønlandstilknytning & Fagspecifikke kompetencer \\
\hline $\begin{array}{l}\text { Kvalifikationer } \\
\text { som efterspørges }\end{array}$ & $\begin{array}{l}\text { Sprogligt og kulturelt } \\
\text { kendskab }\end{array}$ & $\begin{array}{l}\text { Uddannelsesniveau, som } \\
\text { svarer til arbejdets kvalifi- } \\
\text { kationskrav }\end{array}$ \\
\hline Personprofil & $\begin{array}{l}\text { Hjemmehørende, } \\
\text { personer født i Grønland } \\
\text { og grønlandsktalende }\end{array}$ & Uddannede \\
\hline $\begin{array}{l}\text { Problemstilling } \\
\text { ved ansættelse }\end{array}$ & $\begin{array}{l}\text { Få med uddannelsesniveau, } \\
\text { som svarer til kvalifikations- } \\
\text { kravene i jobfunktionen }\end{array}$ & $\begin{array}{l}\text { Fastholdelsesproblemer idet } \\
\text { det ofte er personer uden } \\
\text { grønlandstilknytning som } \\
\text { ansættes }\end{array}$ \\
\hline Fordele ved ansættelse & $\begin{array}{l}\text { Kontinuitet i virksomheden } \\
\text { samt grønlandsk kultur- og } \\
\text { sprogforståelse }\end{array}$ & $\begin{array}{l}\text { Evne til fagligt kompetent, at } \\
\text { løse udfordringerne i job- } \\
\text { funktionen }\end{array}$ \\
\hline
\end{tabular}

Kilde: Baseret på 23 kvalitative interviews med personer med ansættelseskompetencer i henholdsvis det grønlandske erhvervsliv og den offentlige sektor. Interviewene blev gennemført som led i metodeundervisningen 2007 på Institut for Administration Ilisimatusarfik. 
Display 1 er en sammenfatning af de kompetencer der efterspørges ved rekruttering af personale.

På spørgsmålet om, hvorvidt respondenterne ville fortrække en dansker eller en grønlænder, hvis de to personer var lige kvalificerede, svarer alle, at de vil fortrække en grønlænder. Et eksempel kan illustrere det typiske ræsonnement, som følger af ovenstående spørgsmål:

„Jamen, jeg vil vælge at ansætte grønlænderen, helt sikkert. Ingen tvivl om det. Det ville jeg til enhver tid. ['Hvorfor?', spørger intervieweren]. På grund af dobbeltsprogetheden. Hvis de faglige kvalifikationer er de samme, så betragter jeg det som en ekstra kvalifikation. [Intervieweren spørger videre: 'Ja, hvis vi så ligesom siger, at den sproglige kompetence så også lå hos danskeren?']. Altså, så jeg havde to dobbeltsprogede ansøgere ... Så tror jeg stadigvæk, jeg ville vælge at ansætte grønlænderen, fordi vi er i Grønland“ (Respondent A. Upublicerede interviews, metodeundervisning, Institut for Administration, 2007).

Generelt kan det siges, at samtlige 23 interviewede personer anser en opvækst med det grønlandske sprog og den grønlandske kultur som meget værdifuld. En respondent forklarer sig således:

„['Er det vigtigt, at de taler grønlandsk, eller ...?', spørger intervieweren]. Det er meget vigtigt! Jeg taler desværre ikke meget grønlandsk selv, men det er ... det er meget vigtigt ... [F] ordi vi jo arbejder med mennesker, mennesker og følelser; og der udtrykker man sig altså langt bedst på sit modersmål“ (Respondent B. Upublicerede interviews, metodeundervisning, Institut for Administration, 2007).

Og alle angiver, at såfremt de havde kvalificerede grønlandske ansøgere, ville de foretrække dem i en ansættelsessituation.

Flere virksomheder angiver, at de for at få personer med grønlandstilknytning tilrettelægger opkvalificeringsforløb. Argumentet herfor er: „Men vi får så en medarbejder, der er blevet opkvalificeret, som er lokal, og som har tilknytning til samfundet. Den arbejdskraft kan vi bruge mange år i fremtiden, så vi synes jo det er en lille investering i forhold til, hvad det koster at rekruttere en fra Danmark" (Respondent C. Upublicerede interviews, metodeundervisning, Institut for Administration, 2007).

Personerne med ansættelseskompetence foretrækker således folk med grønlandsk etnisk baggrund, specielt fordi det er personer, som kender den grønlandske kultur, kan det grønlandske sprog, og det er forventeligt, at der vil være en større kontinuitet forbundet med ansættelse af en person med grønlandsk tilknytning. Respondent C er meget klar på dette: „Vi har en meget stor gennemsnitsanciennitet blandt lokale medarbejdere - det kniber lidt med de tilkaldte" (Respondent C. Upublicerede interviews, metodeundervisning, Institut for Administration, 2007). 
Problemet består i, at personer med uddannelsesmæssige kvalifikationer med grønlandsk etnisk oprindelse er en meget knap ressource. En respondent udtrykker det således:

„['Interviewer spørger: Når kvalifikationskravet bliver højere, er det så, at du siger, at så har I mest ansat folk med anden nationalitet end grønlandsk?'] Jaaa ... Det har vi i en række tilfælde, men det har noget at gøre med, at der ikke er nogle uddannede heroppe. Der er meget, meget, meget få kokke og tjenere, som er dem, vi sådan primært taler om. Det er ikke nødvendigvis, at de arbejder som kokke eller tjenere, men at de har en uddannelse inden for branchen" (Respondent D. Upublicerede interviews, metodeundervisning, Institut for Administration, 2007).

På baggrund af de interviews, som vi i metodeundervisningen har gennemført, må vi konkludere, at vi ikke har kunnet finde belæg for, at uddannelsesmæssigt velkvalificerede grønlændere diskrimineres. Tværtimod tyder vores data på, at situationen i dag er således, at personer med ansættelseskompetencer er meget bevidste om og prioriterer kvalifikationer, der ligger i at have naturlig adgang til det grønlandske kulturelle videnslager. ${ }^{4}$ Faktisk kan man gå et skridt videre og spørge, om folk med anden etnisk baggrund end grønlandsk - eksempelvis dansk - diskrimineres?

Adspurgt om den ansættelsesprocedure, som en given virksomhed anvender, er positiv særbehandling af grønlændere, svarer den interviewede person:

„For en virksomhed, der arbejder internationalt, vil jeg nok sige 'lidt, ja ...'. For vi făr også ansøgninger fra Danmark, de vil gerne ind i vores virksomhed. Og vi svarer dem pænt, vi optager kun unge med tilknytning til det grønlandske samfund ... Og jeg kunne forestille mig, hvis man var oppe i konkurrence imod nogle EU-foretagender, så vil øhm, så vil pegefingeren sgu' blive løftet. Der er ikke lige adgang for alle EU-borgere til at deltage i det her. Der er begrænsninger, i og med at de skal komme fra det her samfund" (Respondent E. Upublicerede interviews, metodeundervisning, Institut for Administration, 2007).

I tillæg hertil kan nævnes, at flere interviewpersoner påpeger, at en et-nisk grønlænder med de samme uddannelsesmæssige kvalifikationer som en dansker vil blive tilbudt og også få en højere stilling. Et citat kan ligeledes illustrere det: „Men der er også en tendens til, at hvis man har en kandidatgrad som etnisk grønlænder fra Danmark, så kan man gå ind i et niveau højere job, ikke også? Så bliver man typisk ikke ansat som fuldmægtig, når man er færdig. Så går man typisk ind og bliver kontorchef" (Respondent A. Upublicerede interviews, metodeundervisning, Institut for Administration, 2007).

I flere af interviewene dukkede spørgsmålet om politisk pres i en an-sættelsessituation op. Som udgangspunkt var det ikke noget, vi spurgte ind til, men 
et bestemt interview gjorde os opmærksomme på, at dette var et fænomen, som specielt folk i kommunen og i Hjemmestyret var nødt til at forholde sig til.

På spørgsmålet om, hvorvidt en respondent bliver bedt om at tage politiske hensyn med ind i sine overvejelser, svarer respondenten:

\begin{abstract}
„Vi bliver sommetider pressede til at have den nogle gange, fordi vores politikere mener sommetider, at vi er nødt til at ansætte nogle mennesker, som vi måske ikke har så meget lyst til ansætte, fordi de har den baggrund, som de skønner, er politisk korrekt. Og det er nogle andre overvejelser, jeg har med, for jeg vil simpelthen have den, der er bedst ... [M]en selvfølgelig - når man er i et politisk system, så er man nogle gange nødt til rette ind efter de politikere, man er underlagt, ikke? Og derfor kan man nogle gange være nødt til at prioritere lidt anderledes, end man egentlig ville have giort" (Respondent A. Upublicerede interviews, metodeundervisning, Institut for Administration, 2007).
\end{abstract}

I et andet interview redegør en respondent for, hvorledes ansættelsesindstillingerne fra politisk hold modgås, hvorefter der gives pålæg om ansættelse af en anden, end ansættelsesudvalget har indstillet. Respondenten beskriver, at der har været flere sager af den karakter, og at konsekvensen for enkelte har været, at de er gået ned med stress, efter at organisationen er blevet dysfunktionel på grund af inkompetent ledelse. En respondent beskriver konsekvenserne således:

„Problemet for mange unge grønlændere er, at de kommer alt for hurtigt frem. Jeg har allerede set for mange, der brækker halsen. Det er grønlændere, der kom til at lede med det samme. Det vil jeg håbe, man vil være opmærksom på, fordi det er synd for Grønland, men også synd for de personer, der får et knæk" (Respondent F. Upublicerede interviews, metodeundervisning, Institut for Administration, 2007).

Undersøgelsen tyder således på, at der udøves et vist politisk pres på en del af de personer, der ansætter personale. Endvidere at den mangel på uddannet arbejdskraft, der blev redegjort for, afspejles i respondenternes tilkendegivelser af, at det er svært at rekruttere uddannet grønlandsk arbejdskraft.

\title{
Konklusion
}

Grønland var en dansk koloni indtil 1953, hvor det fik status som et dansk amt. I 1979 fik Grønland Hjemmestyre, og i dag er fasen for grønlandsk selvstyre planlagt. På lidt mere end 50 år er Grønland således gået fra at være et fangersamfund til at være et moderne samfund med et udgiftsniveau, der svarer til de øvrige nordiske lande. Udgiftsniveauet finansierer Grønland ikke selv; det er for en relativt stor del finansieret gennem et tilskud fra Danmark. 
Grønlandsk selvstændighed - det som selvstyret gerne skal ende med - forudsætter, at den grønlandske økonomi bliver selvbærende.

I denne artikel er to visioner behandlet for den fortsatte udvikling i Grønland. Den ene pol angiver, at tiden er inde til at grønlandisere gennem ansættelse af grønlændere i ledende stillinger. I forlængelse heraf hævdes det, at de uddannede grønlændere, der er brug for, findes; men at der foregår en diskriminering af veluddannet grønlandsk arbejdskraft, som tilsidesættes til fordel for tilkaldt arbejdskraft.

Den anden vision eller pol i debatten hævder, at nepotisme og deraf følgende dårlig ledelse gennemsyrer det grønlandske samfund. Det leder til et økonomisk ressourcespild, som vil spænde ben for udviklingen af grønlandsk selvstændighed og underforstået en selvbærende grønlandsk økonomi.

Spørgsmålet om rekruttering i Grønland er på den baggrund behandlet. I artiklen er der argumentet for, at det ikke er sandsynligt, at alle de grønlændere findes, som det hævdes, der skal til for at ansætte grønlændere i stillinger, hvor der er et kompetencekrav i form af et vist uddannelsesniveau. Det skyldes, at skøn over uddannelsesniveauet i Grønland siger, at 25 pct. har en kompetencegivende uddannelse, og at 75 pct. af den grønlandske arbejdsstyrkes højeste uddannelsesniveau er folkeskolen. Der er derfor argumentet for, at udbuddet af uddannende personer med grønlandsk etnisk oprindelse ikke er stor nok til at dække efterspørgslen.

Endvidere er der gennem analyse af interviews med personer med ansættelseskompetencer blevet påvist flere forhold. For det første at der ikke diskrimineres mod veluddannede grønlændere. For det andet at såfremt der foregår en diskriminering, er det mod personer med dansk etnisk oprindelse. For det tredje er det påvist, at enkelte af de interviewede personer oplever et politisk pres i forhold til at ansætte bestemte personer. Yderligere at konsekvensen af dette er personlige omkostninger i form af stress og personligt sammenbrud for enkelte af disse personer. Endvidere er omkostningen også på det organisatoriske plan givet ved, at organisationerne med ledelse, der mangler kvalifikationer, er dysfunktionelle.

Undersøgelsens konklusion er derfor, at såfremt Grønland ønsker selvstændighed, er det nødvendigt med en langsigtet satsning, som prioriterer en uddannelsesmæssig opkvalificering af den grønlandske arbejdsstyrke. Når dette er sket, kan stillingerne besættes med uddannelsesmæssigt velkvalificerede personer med grønlandsk etnisk oprindelse. 


\section{Noter}

1. Denne artikels er skrevet på baggrund af et forskningsprojekt, der blev indledt $\mathrm{i}$ metodeundervisningen på Institut for Administration på Ilisimatusarfik. De studerende - Louise Adolfsen, Hanne Nielsen og Arnarulunnguaq Thomassen - og jeg gennemførte de interviews, som er analyseret i artiklen. En stor tak for hjælpen og interessante diskussioner skal hermed gives til de tre studerende.

2. Ved en præsentation i slutningen af 2007 på Ilisimatusarfik rapporterer Den Nordatlantiske Gruppe antallet af grønlændere i Danmark til 18.563. Deres tal har de fra Danmarks Statistik. Uoverensstemmelsen mellem deres tal og de i artiklen opgivne beror på definitionsforskelle. Jeg har systematisk igennem artiklen anvendt definitionen: født i Grønland som operationalisering af „grønlænder“ (Grønlands Statistik - Statistikbanken). Det betyder naturligvis, at jeg i mit tal har børn født af forældre født i Danmark kategoriseret som grønlændere, mens jeg i modsætning til Den Nordatlantiske Gruppe ikke har børn født i Danmark af grønlandske forældre og slet ikke anden eller tredje generationsgrønlændere af blandede ægteskaber.

3. Beregnet ud fra at antallet af skatteborgere i Danmark er 4,745 millioner (opgiort i 2006 - Danmarks Statistik, statistikbanken: Pskat1) og det samlede tilskud er 3.289 millioner kr. plus 850 millioner kr.

4. I artiklen har jeg brugt forskellige datakilder. Det er gjort for at afhjælpe et problem som eksempelvis ringe ekstern validitet i forbindelse med interviews. Med andre datakilder søger jeg at validere konklusionerne. I metodelitteratur benævnes en sådan analysestrategi „metodetriangulering“ (Riis, 2001).

\section{Litteratur}

Ankersen, Pia Vedel (2006). Den politiske legitimitets oprindelse - en fodnote til Easton, Århus: Jura Tryk, Aarhus Universitet

Binzer, Michael (2008). „Nepotisme - Grønlandsk topchef - vennetjenester truer vores selvstændige“, Berlingske Tidende, 3.4, sektion 1 side 12, (ed). Jens Ejsing.

Christiansen, Peter Munk og Lise Togeby (2004). „Grønlands elite“, pp. 80-104 i Gorm Winther,(red.), Demokrati og magt $i$ Gronland, Århus: Aarhus Universitetsforlag.

Durkheim, Émile (2000). Om den sociale arbejdsdeling, København: Hans Reitzels Forlag.

Easton, David (1953). The Political System, An Inquiry into the State of Political Science, New York: Alfred A. Knopf.

Grønlandsk-dansk selvstyrekommission (2008a). Grønlandsk-dansk selvstyrekommissions betenkning om selvstyre i Grønland, http://dk.nanoq.gl/Emner/Landsstyre/Selvstyre/ Groenlandsk-dansk_selvstyrekommission/Betaenkning.aspx, 1.6.2008.

Grønlandsk-dansk selvstyrekommission (2008). Grønlands-dansk selvstyrekommissions betenkning om selvstyre i Grønland - resumé, http://dk.nanoq.gl/Emner/Landsstyre/ Selvstyre/Groenlandsk-dansk_selvstyrekommission/Betaenkning.aspx, 1.6.2008.

Grønlands statistik (2006). Grønland 2006 - Statistisk Arbog, Nuuk: Atuagkat.

Grønlands statistik (2007a). Grønland 2007 - Statistisk Arrbog, Nuuk: Atuagkat.

Grønlands statistik (2007b). Ledighed i byerne, http://www.statgreen.gl/dk/vejv/press/ arbmark/2007-05-23.pdf, 1.6.2008.

Johansen, Elisabeth Ravn (2007a). „Grønlandiseringen skal fuldføres“, Sermitsiaq, 25.5. Johansen, Elisabeth Ravn (2007b). „Inussuk: Ja, vi er nationalister“. Webavisen.gl, 12.6. http://www.webavisen.gl/?Id=4962, 12.6.2007.

Johansen, Lars-Emil (2003). „De onde lo og de gode græd“, Fyllands-Posten, 17.1., 1. sektion, p. 11. 